\title{
COVID-19: ECONOMIC RECESSION OR DEPRESSION? ${ }^{\circ}$
}

\author{
COVID-19: ¿RECESIÓN O DEPRESIÓN ECONÓMICA?
}

Mario Arturo Ruiz Estrada*

enviado: 15 abril 2020 - aceptado: 28 abril 2020

\begin{abstract}
This paper is interested to introduce a new macroeconomic indicator to evaluate the impact of any massive pandemic such as COVID-19 on the world economy performance in the short run (1 year) and long run (10 years). The new macroeconomic indicator is entitled "The Economic Uncontrolled Desgrowth from COVID-19 (- $\delta_{\mathrm{CO}}$ VID-19)." In fact, the new macroeconomic indicator assumes that always COVID-19 is going to be the major factor to generate a large economic leakage on the final GDP formation anytime and anywhere. Additionally, the same paper is willing to evaluate two post-COVID-19 possible scenarios. The first scenario: if COVID-19 is going to generate a short economic recession, then the world economy gross domestic product can delay between two and three years. The second scenario: if COVID-19 is going to produce a large economic depression, then the world economy gross domestic product can take easily between five and ten years such as the case of the world great depression of 1928. From now, the economists need to decide between two possible choices to solve these two types of economic crisis (recession or depression): The first choice is the uses of the classical economic policies - fiscal or monetary- from past experiences (Keynesians and Monetarists). The second choice is the creation of new and innovative polices approaches to reduce the COVID-19 damage under the support of new theoretical and methodological approaches.
\end{abstract}

Keywords: economic growth, economic desgrowth, macroeconomics, policy modeling. JEL Code: O47.

Ruiz Estrada, M.A. (2020). COVID-19: Economic Recession or Depression? Estudios económicos, 37 (75), 139-147.

* Social Wellbeing Research Centre (SWRC), University of Malaya. E-mail: marioruiz@um.edu.my 


\section{Resumen}

Este documento se propone desarrollar un nuevo indicador macroeconómico para evaluar el impacto de cualquier pandemia masiva como COVID-19 en el desempeño de la economía mundial a corto plazo (1 año) y largo plazo (10 años). El nuevo indicador macroeconómico se denomina "El desencadenamiento económico no controlado de COVID-19". De hecho, el nuevo indicador macroeconómico supone que COVID-19 será siempre el principal factor para generar una gran pérdida económica en términos de PIB en cualquier momento y en cualquier lugar. Además, se evalúan dos posibles escenarios posteriores a COVID-19. El primer escenario indica que si COVID-19 genera una breve recesión económica, entonces el aumento del producto interno bruto de la economía mundial puede retrasarse entre dos y tres años. El segundo escenario supone que si COVID-19 produce una gran depresión económica, entonces el crecimiento producto interno bruto de la economía mundial puede tomar fácilmente entre cinco y diez años, como el caso de la gran depresión mundial de 1928. A partir de ahora, los economistas necesitan decidir entre dos posibles opciones para resolver estos dos tipos de crisis económica (recesión o depresión): la primera opción son los usos de las políticas económicas clásicas - fiscales o monetarias - de experiencias pasadas (keynesianos y monetaristas). La segunda opción es la creación de enfoques de políticas nuevos e innovadores para reducir el daño de COVID-19 con el apoyo de nuevos enfoques teóricos y metodológicos.

Palabras clave: crecimiento económico, decrecimiento económico, macroeconomía, diseño de políticas.

Código JEL: 047. 


\section{AN SHORT REVIEW ABOUT THE ECONOMIC UNCONTROLLED DES- GROWTH FROM COVID-19 $\left(-\delta_{\text {COVID-19 }}\right)$}

This research paper tries to evaluate about the origins and behavior of economic growth through the formulation of different theories. The different economic growth theories are using different factors, laws, assumptions, models, and techniques to explain how economic growth works. For example, the case of Solow (1956, p. 70), Swan (1956, p. 340) and Meade (1961, p. 500), Keynes (1936), Lucas (1988, p. 7), Romer (1986), Kalecki (1936, p. 360), Hicks (1981, p. 140), and Kaldor (1959, p. 288). The follow economic growth theories are looking for the origins, reasons, and conditions to maximize the economic growth for any nation from an expansionism approach (non-exist limits for economic growth). The concept of expansionism approach is based on different mechanisms (policies) and conditions (incentives) to facilitate the expansion of production, spending, and distribution of any country. However, our concept about economic growth is based on the constractionism approach (always exist limits for economic growth). In fact, the constractionism approach explains how in the GDP formation process always keep in constant losses (economic leakages) that can generate several damage on the final GDP formation of any nation. The main objective is to keep all possible economic leakages under a strict control constantly. In addition, we need to assume that any economic leakage can affect directly or indirectly on the final GDP formation process. According to this research, we propose a new theoretical approach to evaluate economic growth under the observation of possible small or large losses (or economic leakages) constantly in the GDP formation process systematically, we are named "economic desgrowth $(-\delta)$ ". According to the economic desgrowth, we are referring to the constant losses of economic growth (or economic leakages) in the GDP formation process in a fixed period of time that is equivalent to one year. Hence, in this research paper tries to reinvent the uses of economic desgrowth $(-\delta)$ concept under the inclusion of a new economic leakage such as COVID-19. The new economic desgrowth is renamed as the economic uncontrolled desgrowth from COVID-19 (- $\left.\delta_{\text {COVID-19 }}\right)$. The $-\delta_{\text {COVID-19 }}$ calculation involves the impact of COVID-19 in the GDP formation process in one year. The $-\delta_{\text {COVID-19 }}$ encourages to keeps a constant control on the expansion of COVID-19 to keep healthy the GDP formation process of any nation in the short and long run. We assume that if COVID-19 keeps in a constant expansion in the long run, then it is possible to damage the GDP formation constantly for many years until we can arrive to a deep economic depression. 


\section{INTRODUCTION TO THE ECONOMIC UNCONTROLLED DESGROWTH FROM COVID-19 $\left(-\delta_{\text {COVID-19 }}\right)$}

Initially, we are defining the Economic Uncontrolled Desgrowth from COVID-19 "as an indicator that can show the impact of any epidemic as the main economic leakage that affect directly on the GDP formation process in one year". The quantification of the $-\delta_{\text {COVID-19 }}$ is based on the uses of a finite interval of probability between zero and one. According to the $\delta_{\mathrm{COVID}-19}$, we assume that always exist an irregular oscillation into different periods of time. Additionally, we assume that the world economy always keeps in a permanent chaos under different levels of vulnerability according to different magnitudes of irregularities. The $-\delta_{\text {COVID-19 }}$ request to apply random intervals to make possible analyze possible unexpected scenarios by different non-controlled scenarios. The unexpected scenarios cannot be monitored easily from the traditional linear and non-liner modeling. The $-\delta_{\text {COVID-19 }}$ assumes that our world economy keeps in a constant chaos.

\section{MEASUREMENT OF THE ECONOMIC UNCONTROLLED DES- GROWTH FROM COVID-19 (-8COVID-19)}

The measure of the $-\delta_{\text {COVID-19 }}$ is based on the application of large number of multi-dimensional first partial derivatives in real time (-) (Ruiz Estrada, 2017, p. 2120). It is according to the uses of a large list of non-controlled events probability between the present time (this year $=\mathrm{t}+1)$ and the past time (last year $=\mathrm{t}-1$ ) (see Expression 1).

$$
\begin{aligned}
& \alpha \mathrm{ij}=\partial \alpha \mathrm{ijt}+1 / \mathrm{d} \partial \alpha \mathrm{ijt}-1
\end{aligned}
$$

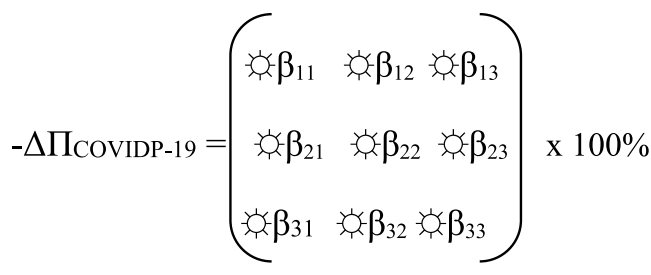

Therefore, our model has nine growth rates such as the total contagious cases daily marginal rates from COVID-19 ( $\left.\beta_{11}\right)$, death cases daily marginal rate from COVID-19 ( $\beta_{12}$ ), no recovered cases daily marginal rate from COVID-19 $\left(\beta_{13}\right)$, recovered cases daily marginal rate from COVID-19 ( $\left.\beta_{21}\right)$, potential 
cases per capita marginal rate for COVID-19 ( $\left.\beta_{22}\right)$, people in quarantine marginal rate from COVID-19 ( $\left.\beta_{23}\right)$, big cities population concentration per capita marginal rate infected by COVID-19 ( $\left.\beta_{31}\right)$, the vaccination R\&D time to eradicate marginal rate for COVID-19 ( $\beta_{32}$ ), the number of hospitals, medical doctors, and nurses full busy per capita marginal rate in case of COVID-19 ( $\left.\beta_{33}\right)$. Each growth rate is applied multidimensional first partial differentiation $(\partial)$ in real time (-) under the assumption of Omnia Mobilis assumption (Ruiz Estrada, 2011, p. 525 and Ruiz Estrada \& Park 2018, p. 3) (See Expression 2).

Subsequently, to measure the economic leakage from COVID-19 $\left(-\Delta \Pi_{\text {COVIDP-19 }}\right)$ is based on the calculation of a single determinant $(\Delta)$ from a matrix three by three under the uses of nine different marginal rates that was mentioned before (see Expression 2). Finally, the measurement of the $-\boldsymbol{\delta}_{\text {COVID-19 }}$ is equal to multiply the $\mathrm{GDP}_{\mathrm{t}-1}$ (the last year GDP formation growth rate) by $-\Delta \Pi_{\text {COVIDP-19 }}$ (see Expression 3). The last year GDP formation growth rate $\left(\mathrm{GDP}_{\mathrm{t}-1}\right)$ is equal to the last growth rate in real prices from the last year.

$$
-\delta_{\mathrm{COVID}-19}=\left(\mathrm{GDP}_{\mathrm{t}-1}\right) \times\left(-\Delta \Pi_{\mathrm{COVIDP}-19}\right)
$$

The modeling of the $-\delta_{\text {COVID-19 }}$ requests the application of the Omnia Mobilis assumption by Ruiz Estrada (2011) to generate the relaxation of economic leakage from COVID-19 respectively. In fact, we can observe that $-\boldsymbol{\delta}_{\text {COVID-19 }}$ can generate a considerable reduction of the final total GDP formation growth rate $\left(\mathrm{GDP}_{t}\right)$. Finally, the $\mathrm{GDP}_{\mathrm{t}}$ is equal to the last year GDP formation growth rate $\left(\mathrm{GDP}_{\mathrm{t}-1}\right)$ minus the $-\delta_{\text {COVID-19 }}$ followed by expression 4 .

$$
\mathrm{GDP}_{\mathrm{t}}=\mathrm{GDP}_{\mathrm{f}}-\left(-\delta_{\mathrm{COVID}-19}\right)
$$

\section{THE VISUALIZATION OF THE GDP DESGROWTH}

According to figure one is possible to observe how the $-\boldsymbol{\delta}_{\text {COVID-19 }}$ affect directly on the final total GDP formation growth rate $\left(\mathrm{GDP}_{t}\right)$. The main point in discussion is that if the size of $-\boldsymbol{\delta}_{\text {COVID-19 }}$ keeps in a constant expansion, then GDP can experience a constant contraction in the consumption (private and public), investment (savings), government (taxation and spending). Accordingly to this research, if the $\mathrm{GDP}_{t}$ keeps smaller in the long run, then any economy can experience a deep economic depression. We define depression as a massive constant economic leakage from COVID-19 ( $\left.-\Delta \Pi_{\text {COVIDP-19 }}\right)$ that can directly impact on the $-\delta_{\text {COVID-19 }}$ expansion. On another hand, we define recession as a smaller or regular 
size of $-\Delta \Pi_{\text {COVIDP-19 }}$ that can affect the $-\delta_{\text {COVID-19 }}$. At the same time, the $-\delta_{\text {COVID-19 }}$ is going to impact directly on the $\mathrm{GDP}_{t}$ performance in the short run. Therefore, the size of $\mathrm{GDP}_{\mathrm{t}}$ is going to fix the existence of recession or depression. Our argument is that the reduction of $-\Delta \Pi_{\text {COVIDP-19 }}$ in the $\mathrm{GDP}_{t}$ depends on the time framework of COVID-19 duration. Moreover, if we keep for long time COVID-19 then the damage is going to be huge until we can get in a deep economic depression. The COVID-19 damage is going to stop until exist the vaccination in the market worldwide. If suppose we lose the full control on COVID-19 worldwide, then the $-\Delta \Pi_{\text {COVIDP-19 }}$ and $-\delta_{\text {COVID-19 }}$ is going to beyond our control. The final impact of $-\delta_{\text {COVID-19 }}$ damage can generate a large unemployment, hyperinflation, and large poverty levels considerably. Finally, the reduction of $-\Delta \Pi_{\text {COVIDP-19 }}$ is directly connected to the COVID-19 faster medical solution (vaccination) and a strict control on the people mobility (quarantine) in the short run (see Figure 1).

Figure 1. Graphical Representation of the Economic Leakage from COVID-19 $\left(-\Delta \Pi_{\text {COVIDP-19 }}\right)$, the Economic Uncontrolled Desgrowth from COVID-19 $\left(-\delta_{\mathrm{COVID}-19}\right)$, the last year GDP formation growth rate $\left(\mathrm{GDP}_{\mathrm{t}-1}\right)$, and the final total GDP formation growth rate $\left(\mathrm{GDP}_{t}\right)$

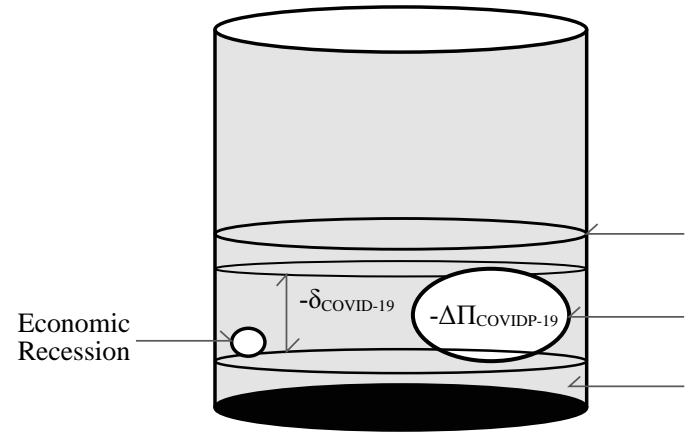

The last year GDP

formation growth rate $\left(\mathrm{GDP}_{\mathrm{t}-1}\right)$

Economic

Depression

The final total GDP formation growth rate $\left(\mathrm{GDP}_{\mathrm{t}}\right)$

Sourse: Own elaboration.

\section{A SIMULATION OF THE ECONOMIC UNCONTROLLED DESGROWTH FROM COVID-19 (-8COVID-19): WORLDWIDE}

According to our simulator, we try to evaluate the impact of COVID-19 impact in the world economy according to different simulations (a total of 100 simulations). The simulation number 55, we have an economic leakage from COVID-19 $\left(-\Delta \Pi_{\text {COVIDP-19 }}=0.39\right)$. The $-\Delta \Pi_{\text {COVIDP-19 }}$ has nine growth rates such 
as the total contagious cases daily marginal rate from COVID-19 ( $\left.\beta_{11}=0.05\right)$, death cases daily marginal rate from COVID-19 ( $\left.\beta_{12}=0.07\right)$, no recovered cases daily marginal rate from COVID-19 ( $\left.\beta_{13}=0.05\right)$, recovered cases daily marginal rate from COVID-19 ( $\left.\beta_{21}=0.07\right)$, potential cases per capita marginal rate for COVID-19 ( $\beta_{22}=0.26$ ), people in quarantine marginal rate from COVID-19 $\left(\beta_{23}=0.55\right)$, big cities population concentration per capita marginal rate infected by COVID-19 $\left(\beta_{31}=0.15\right)$, the vaccination $R \& D$ time to eradicate marginal rate for COVID-19 ( $\left.\beta_{32}=0.08\right)$, the number of hospitals, medical doctors, and nurses full busy per capita marginal rate in case of COVID-19 ( $\left.\beta_{33}=0.25\right)$. Hence, if the last year GDP formation growth rate $\left(\mathrm{GDP}_{\mathrm{t}-1}\right)$ was equal to $3 \%$ then the economic uncontrolled desgrowth from COVID-19 $\left(-\boldsymbol{\delta}_{\mathrm{COVID}-19}\right)$ is equal to $\left(\mathrm{GDP}_{\mathrm{t}-1}=3 \% \mathrm{x}\right.$ $\left.-\Delta \Pi_{\text {COVIDP-19 }}=0.39=1.47 \%\right)$. Subsequently, we expect that the final total GDP formation growth rate $\left(\mathrm{GDP}_{t}\right)$ between 2019 and 2020 is equal to $\left(\left[\mathrm{GDP}_{\mathrm{t}}=3 \%\right.\right.$ $\left.\left.\left(-\boldsymbol{\delta}_{\text {COVID-19 }}=1.47 \%\right)\right]=1.53 \%\right)$. If COVID-19 stops after 5 months (July 2020), then we can experience only a short recession between two (2022) to three years (2023) (see Figure 2).

The eighty-eight simulation is under an economic leakage from COVID-19 $\left(-\Delta \Pi_{\text {COVIDP-19 }}=0.80\right)$. The $-\Delta \Pi_{\text {COVIDP-19 }}$ also has nine growth rates such as the total contagious cases daily marginal rate from COVID-19 $\left(\beta_{11}=1\right)$, death cases daily marginal rate from COVID-19 ( $\left.\beta_{12}=0.50\right)$, no recovered cases daily marginal rate from COVID-19 $\left(\beta_{13}=0.25\right)$, recovered cases daily marginal rate from COVID-19 ( $\left.\beta_{21}=0.20\right)$, potential cases per capita marginal rate for COVID-19 $\left(\beta_{22}=0.95\right)$, people in quarantine marginal rate from COVID-19 ( $\left.\beta_{23}=1\right)$, big cities population concentration per capita marginal rate infected by COVID-19 $\left(\beta_{31}=0.75\right)$, the vaccination R\&D time to eradicate marginal rate for COVID-19 $\left(\beta_{32}=0.25\right)$, the hospitals, medical doctors, and nurses full busy per capita marginal rate in case of COVID-19 $\left(\beta_{33}=1\right)$. Hence, if the last year GDP formation growth rate $\left(\mathrm{GDP}_{\mathrm{t}-1}\right)$ was equal to $3 \%$, then the economic uncontrolled desgrowth from COVID-19 $\left(-\boldsymbol{\delta}_{\text {COVID-19 }}\right)$ is equal to $\left(\mathrm{GDP}_{\mathrm{t}-1}=3 \% \times\left(-\Delta \Pi_{\text {COVIDP-19 }}=0.80=\right.\right.$ $2.40 \%)$. Subsequently, we expect that the final total GDP formation growth rate $\left(\mathrm{GDP}_{\mathrm{t}}\right)$ between 2019 and 2020 is equal to $\left(\left[\mathrm{GDP}_{\mathrm{f}}=3 \%-\left(-\boldsymbol{\delta}_{\mathrm{COVID}-19}=2.40 \%\right)\right]\right.$ $=0.6 \%$ ). If COVID stops after one year (March 2021) then we can experience an economic recession between six (2027) to eight years (2029) (see Figure 2). 
Figure 2. Final Impact of COVID-19 after Five Months and One Year

COVID-19 for Five Months

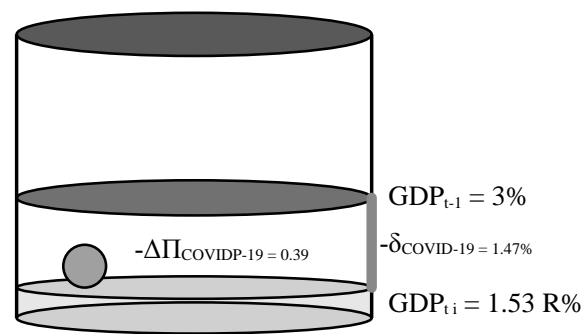

COVID-19 for One year

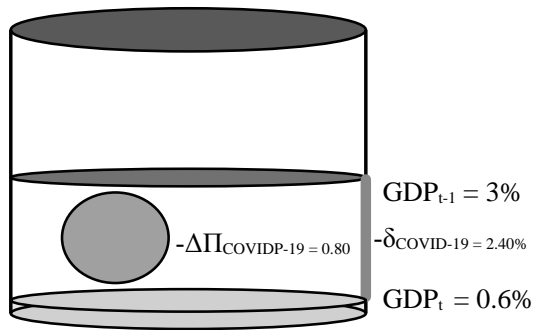

Sourse: Own elaboration.

\section{CONCLUSION}

This paper concluded that the magnitude of COVID-19 damage on the world economy depends on the time is going to take the vaccination implementation and we keep strict controls on the people mobility domestically and internationally (quarantines). We probe with our simulator that the COVID-19 crisis cannot be more than five months. It is to avoid a deep economic depression in the near future. According to our results, a possible economic depression can take between six to eight years minimum. Now, we can observe that any pandemic such as COVID-19 can affect severally on the final formation of the GDP in anywhere and anytime.

\section{REFERENCES}

Barro, R. J. (1997). Determinants of Economic Growth: A Cross-Country Empirical Study. Cambridge, MA: MIT Press.

Hicks, J. (1981). IS-LM: An Explanation. Journal of Post Keynesian Economics, 3 (2), 139-155.

Kalecki, M. (1936). Comments on the Macrodynamic Theory of Business Cycles. Econometrica, 4 (4), 356-360.

Kaldor, N. (1959). Economic Growth and the Problem of Inflation. Economica, 26 (104), 287-298. 
Keynes, J. M. (1936). The General Theory of Employment, Interest and Money. En Keynes, J. M. Collected Works, vol. 7. London: Macmillan.

Lucas, R. (1988). On the Mechanics of Economic Development. Journal of Monetary Economics, 22 (1), 3-42.

Meade, J. E. (1961). A Neo-Classical Theory of Economic Growth. The Journal of Political Economy, 69 (5), 498-500.

Romer, P. M. (1986). Increasing Returns and Long-run Growth. Journal of Political Economy 94 (5), 1002-1037.

Ruiz Estrada, M. A. (2011). Policy Modeling: Definition, Classification and Evaluation. Journal of Policy Modeling, 33 (4), 523-536.

Ruiz Estrada, M. A. (2017). An Alternative Graphical Modeling for Economics: Econographicology. Quality and Quantity, 51 (5), 2115-2139.

Ruiz Estrada, M. A., Park, D. (2018). The Past, Present, and Future of Policy Modeling. Journal of Policy Modeling, 40 (1), 1-15.

Solow, R. (1956). A Contribution to the Theory of Economic Growth. Quarterly Journal of Economics, 70 (1), 65-94.

Swan, T. W. (1956). Economic Growth and Capital Accumulation. Economic Record, 32 (2), 334-361.

World Health Orgranication (WHO) (2020). COVID-2019 Situation Reports. Retrieved from https://www.who.int/emergencies/diseases/novel-coronavirus-2019/situation-reports/

(C) 2020 por los autores; licencia no exclusiva otorgada a la revista Estudios económicos. Este artículo es de acceso abierto y distribuido bajo los términos y condiciones de una licencia Atribución-No Comercial 4.0 Internacional (CC BY-NC 4.0) de Creative Commons. Para ver una copia de esta licencia, visite http://creativecommons.org/licenses/by-nc/4.0 
ESTUDIOS ECONOMICOS 